\title{
LILITH KRAUSHAAR. Botitas Negras en Calama. Género, magia y violencia en una ciudad minera del norte de Chile Santiago, Ceibo Ediciones, 2016, 398 págs.
}

El libro que reseño me evocó la frase de un texto de Robert Castel que decía "Ganarse la vida para perderla", pero además el singular y brutal ingreso de una mujer al panteón politeísta de la religiosidad popular pasando por su sacrificio. La verdad es que no me despegué por varios días de su apasionante lectura. Menuda conversación y menudo tema el que plantea el texto y el problema que se aborda y desarrolla en sus más de trescientas páginas.

El tema y el trabajo de Lilith Kraushaar nos coloca en el presente, ya que no estamos lejos de un problema que en nuestra sociedad es recurrente, cercano y casi cotidiano, aunque no todas las mujeres asesinadas se transformen como Irene Iturra Saéz en figuras de culto, como ocurrió con "Botitas Negras", renombrada de esta manera tras su brutal asesinato por la ciudad minera de Calama.

Es un caso ciertamente singular, pero de ninguna manera único puesto que, en sus conclusiones, la misma autora nombra a otras mujeres de Antofagasta y Copiapó que también corren igual suerte, víctimas de asesinato y descuartizamiento e igual ingreso al panteón politeísta de la religiosidad popular. El pueblo no pareciera establecer diferencias como objetos de culto entre una virgen y una prostituta sacrificada.

Es la primera impresión que surge de la inclusión de una joven asesinada como objeto de culto popular, lo que la coloca en el mismo horizonte de las figuras producidas por la institución eclesiástica, vírgenes, limpias y virtuosas, así como se hace visible en numerosos ejemplos que cristalizan en las animitas que de alguna forma subvierten la propaganda iconográfica que ha desplegado la Iglesia católica, creando una religiosidad "por abajo" en los bordes y extramuros institucionales. No obstante, cuando Irene, transformada en Botitas Negras, ingresa al panteón politeísta de la religiosidad popular y es objeto de ruego colectivo, es su sacrificio el que le abre las puertas de ese lugar.

Botitas Negras en Calama. Género, magia $y$ violencia en una ciudad minera del norte de Chile publicado por la editorial Ceibo es un libro organizado en dos partes, de muy fácil y rápida lectura, pese a su extensión y aun considerando la sordidez de la violencia del asesinato de esta joven del mundo bohemio de la ciudad minera hacia fines de los años sesenta.

Frente a la violencia del hecho cuya víctima es Irene Iturra Saéz, que también se llamó María y a veces Marcela, procurando hacerse invisible en sus tránsitos por diversas ciudades del país y prostíbulos; su segunda parte nos hace dar vuelta la mirada y nos enfrenta a la figura de culto a la cual los lugareños de todas las edades y sexos claman para rogar por mejor suerte en el plano de la pareja, del trabajo, de la salud, de los estudios. Su altar allá en el cementerio de Calama se transforma en el recinto de 
ruegos y eventual producción de milagros para quienes lo frecuentan, quienes quieren pedir y quienes quieren establecer un diálogo, una conversación con este otro nombre, establecido una vez que es descubierto el cadáver brutalmente destrozado que portaba botas negras, lo primero que vieron los que lo descubrieron, de ahí su último nombre: Botitas Negras.

Para producir un texto dividido en dos grandes partes, la autora se ha valido de distintas fuentes; una primera parte de carácter documental que requirió la revisión del Archivo Judicial, la lectura de cartas de Irene Iturra, entrevistas a personas que la conocieron, los archivos de prensa; una segunda parte, de carácter etnográfico, en el "Altar" de Botitas Negras, junto a la revisión de las peticiones escritas de sus seguidores durante dos años.

Estamos frente a dos figuras diferentes unidas por el acto sacrificial de la muerte violenta cometida por alguien, presumiblemente un hombre. Es este sacrificio de una mujer que se gana la vida en el mundo bohemio para perderla, lo que marca el tránsito de la prostitución a la santidad. Dos figuras diferentes en el tiempo, Irene en vida desplazándose entre la zona de Chillán y Calama, Botitas en cambio solicitada como figura milagrosa en un Altar construido por sus mismos seguidores en el Cementerio de Calama.

Este libro resulta insinuante en términos de la construcción de los géneros en los años en que vive su protagonista, a diferencia muchas veces del lenguaje de los especialistas, cuyas interpretaciones podrían transitar en los debates sobre lo profano y lo sagrado o la violencia y lo sagrado, temas abundantemente examinados por la antropología.
Especialmente en su primera parte, la autora nos habla de las aventuras y desventuras de Irene o María o Marcela, un mismo personaje que se despliega y desplaza bajo diferentes nombres según el lugar que habite y trabaje, y que parece establecer una compleja relación con sus clientes y sus amantes y con su pareja minero en Calama. En una de las cartas citadas en el texto, Irene se refiere a los hombres como meros órganos sexuales, de hecho, pregunta a su amiga cómo están "los picos"; escapa frecuentemente de una relación estable con su pareja, establece otras relaciones con amantes, descontando aquellas que tiene con sus clientes. Finalmente, no obedece a ninguna clasificación rígida pues transita entre una y otra, ya sea secuencialmente o en un mismo momento. Muy joven ya se ha trasladado por varias ciudades del sur llegando a Calama y varias veces vuelve al sur, concretamente a Chillán donde hay un lugar conocido que la acoge y al que frecuentemente vuelve.

Es decir, esta mujer es la contracara de la figura femenina convencional de los años sesenta, y no solo por trabajar en la prostitución sino por transitar entre varios lugares, desprenderse de su nombre para adoptar otro y sobre todo, relacionarse con los hombres de manera bastante transgresora incluso para el medio bohemio. Es una mujer en constante fuga, y que muestra apreciaciones despreciativas y burlonas sobre la clientela masculina, que tampoco se satisface con la pareja estable apropiada al trabajador minero. Es alguien que va y viene entre lugares, ciudades, prostíbulos, casa, calle, caminos.

¿Es esta la causa de su asesinato? Rita Segato a propósito de los masivos feminicidios en Ciudad Juárez habla de estos crímenes 
como "actos comunicativos" que comete la fratria masculina perteneciente al mundo subterráneo del tráfico, pero que impone su ley en la ciudad como marca territorial. Evidentemente estamos hablando de problemas distintos pero la idea del crimen como acto comunicativo que imponen los hombres en la ciudad minera, para marcar los límites en que deben situarse las mujeres, no se aleja de la hipótesis de que una mujer joven insumisa merezca tal castigo ejemplarizador en un mundo masculinizado como Chuquicamata y Calama, donde la virilidad debe ser constantemente afirmada, pues coexiste con el mundo de las mujeres bajo constante sospecha y vigilancia, porque el hombre minero no puede ejercer control permanente sobre ellas.
No quiero terminar mi comentario dejando entrever que los crímenes perpetrados contra mujeres de cualquier condición sean particulares a una ciudad minera y a tiempos pasados, dada su enorme actualidad en nuestro país, en Latinoamérica y otras latitudes de los feminicidios. Las estructuras elementales de la violencia, como diría Segato, restan soberanía como lo vemos todos los días a los cuerpos femeninos. Esta autora recurre al lema: "cuerpo de mujer, peligro de muerte". Por tanto, el problema que aborda Lilith Kraushaar es más universal de lo que pudiera pensarse. -

Ximena Valdés S.

Centro de Estudios y Desarrollo de la

Mujer (CEDEM) 